State Ownership Effect on Firms’ FDI Ownership Decisions under Institutional Pressure: A

Study of Chinese Outward Investing Firms

\author{
Lin Cui \\ Research School of Management \\ ANU College of Business and Economics \\ The Australian National University \\ Canberra, ACT 0200, Australia \\ Tel: +61261256190 \\ Fax: +61261258796 \\ Email: lin.cui@anu.edu.au \\ Fuming Jiang* \\ School of Management \\ Curtin Business School \\ Curtin University \\ Perth, WA 6845, Australia \\ Tel: +61 892661136 \\ Fax: +61 892667897 \\ Email: fuming.jiang@curtin.edu.au
}

* Correspondent author

This paper was accepted in December 2011 for publication in

Journal of International Business Studies 


\title{
State Ownership Effect on Firms’ FDI Ownership Decisions under Institutional Pressure: A Study of Chinese Outward Investing Firms
}

\begin{abstract}
This study investigates the effect of state ownership on Chinese firms' foreign direct investment (FDI) ownership decisions. It adopts a political perspective to extend the application of institutional theory in international business research. Specifically, it examines firms' heterogeneous responses to external institutional processes during foreign market entry, while taking into consideration the political affiliation of firms with the external institutions. We argue that state ownership creates the political affiliation of a firm with its home country government, which increases the firm's resourcedependence on home country institutions, while at the same time, influences its image as perceived by host country institutional constituents. Such resource-dependence and political perception increase firms' tendency to conform to, rather than resist, isomorphic institutional pressures. We tested our hypotheses using primary data of 132 FDI entries made by Chinese firms during 2000-2006, and we found that the effects of home regulatory, host regulatory, and host normative pressures on a firm to choose a joint ownership structure were stronger when the share of equity held by state entities in the firm was high.
\end{abstract}




\section{INTRODUCTION}

Institutional theory has enriched our understanding of firms' international business strategies. Prior studies found that external institutional constraints and pressures can influence firms’ strategic choices in foreign direct investment (FDI) (Brouthers, 2002; Chan \& Makino, 2007; Meyer, Estrin, Bhaumik, \& Peng, 2009; Yiu \& Makino, 2002). Beyond the ‘top-down’ effects (of institutions on organizations) that have dominated early studies (Scott, 2005), researchers also attempt to explore the role of firms in their institutional environments and the subsequent heterogeneous firm responses to external institutional pressures (Kostova, Roth, \& Dacin, 2008; Oliver, 1991).

When studying firm response to external institutional pressures, prior studies recognize firms as active agents who have the potential of reconstructing the rules and norms of their institutional fields (DiMaggio, 1988; Oliver, 1991; Scott, 2005). The basic premises of these studies are that firm self-interests may not align with those of the institutions, and that firms are driven by their selfinterests to influence the institutional processes. While these assumptions apply to firms who are structurally separate from external institutions, they may not hold for firms who are themselves a part of the institutions, in particular, the state-owned enterprises (SOEs). SOEs are, by definition, assets of home country governments, which make them a part of their home country institutions. Such an affiliation does not exempt firms from external institutional pressures; rather, it changes the nature of firms' responses to the pressures. For instance, while pursuing their business objectives, SOEs can be required to serve the political mandates of the state and align their interests with the home institutions rather than challenge these interests (Scott, 2002; Zhang, Zhou, \& Ebbers, 2011). Because of their affiliation with the home institutions, when they invest overseas, SOEs can be perceived by host country institutions, not simply as business entities, but also as political actors (Globerman \& Shapiro, 2009; He \& Lyles, 2008). Such a perception can pose challenges to SOEs' institutional processes in host countries (Luo \& Rui, 2009; Peng, Wang, \& Jiang, 2008). The political nature of the institutional processes SOEs engage in is not captured by the existing theory that views firms as active agents in their institutional environment (e.g., Oliver, 1991). SOEs as political affiliates are different from active agents in that their responses to institutional pressures are not solely motivated by self-interests, 
but also the interests of the institutions they are affiliated with. Existing theory does not adequately explain the influence of political affiliation on firms' responses to external institutional pressures.

In this study, we explore the role of state ownership in firms' institutional processes in home and host countries. Specifically, we examine the effect of state ownership on the strengths of external institutional pressures that influence firms' FDI ownership decisions. We focus on firm’s FDI ownership decision as it is arguably one of the most important strategic decisions firms face when conducting FDI. Firms make FDI ownership decisions by choosing between a joint ownership structure and a sole ownership structure in their foreign affiliates ${ }^{1 .}$ The result of this decision has longterm consequences and significant performance implications on firms (Brouthers, 2002; Brouthers \& Hennart, 2007).

We advance a political perspective to examine the effect of state ownership on firms' FDI ownership decisions under home and host country institutional pressures. We argue that state ownership creates a political linkage between a firm and its home country institutions which allows the firm to be resource-dependent on the home institutions, and also influences the image of the firm as perceived by host country institutions. Both the resource-dependence and political image have consequences on the firm's response to external institutional pressures. A firm’s conformity to institutional pressures is a function of external dependence (DiMaggio \& Powell, 1983). The more a firm is dependent on the institution that exerts the pressure, the more likely it will conform to, rather than resist, that pressure (Oliver, 1991). Firms also vary in their abilities to gain institutional legitimacy without being isomorphic. Firms who can create a positive image (as perceived by institutional constituents) about the firms' internal routines, structures and norms can gain legitimacy through negotiation (Kostova et al., 2008; Westney, 1993); whereas firms whose images are negatively perceived will be more subject to isomorphic pressures due to the lack of an alternative legitimizing mechanism. Based on these consequences of political affiliation, we contend that state ownership can influence firms' responses to external institutional pressures, or in other words, state ownership moderates the effects of external institutional pressures on firms' FDI ownership decisions. 
We choose Chinese outward FDI as the empirical context to study the moderating effect of state ownership. The Chinese context provides two advantages for this study. First, while the Chinese economy has become increasingly diverse and plural (Rugman \& Li, 2007; Tan \& Tan, 2005), state owned or controlled firms remain the dominant force in the country's outward FDI (Chen \& Young, 2010; Morck, Yeung, \& Zhao, 2008). The prevalence of state ownership and the variation of the level of state ownership in individual Chinese firms allow us to capture its effect in firms' decision-making. Second, the institutional environment of Chinese outward FDI is dynamic and diverse, which makes it an ideal context to test our hypotheses. Chinese outward FDI spreads in over 170 countries with various institutional conditions. Moreover, Chinese government’s policies towards outward FDI change constantly (Luo, Xue, \& Han, 2010), and that creates different home institutional pressures across time and industries.

The main contribution of this study is two-fold. First, this study contributes to institutional theory and its application in international business research. Scott (2005) notes that institutional theory should be advanced from the prevailing top-down models of institutional effect towards the understanding of institutional process that incorporates both institutional influence and firm responses. Theoretical development is underway to explain the heterogeneous firm responses to institutional pressures. Prior studies focus on firms that are structurally separate from institutions, who are able to make strategic responses (Goodrick \& Salancik, 1996; Oliver, 1991) or even challenge the boundary of institutional field (Kostova et al., 2008). Our study extends this theoretical development to firms that are structurally affiliated with institutions. Their abilities and willingness to influence or challenge the institutions can be hindered due to the resource-dependence on home country government as well as political liability in the host countries. Accordingly, we advance a political perspective to study the effect of state ownership on firms' responses to external institutional pressures.

Second, this study also contributes to the empirical research on the internationalization of emerging economy firms, especially those from China. The surge of Chinese outward FDI has attracted academic attention to investigate the characteristics of Chinese firms and their institutional 
environments that shape firms' internationalization strategies (Child \& Rodrigues, 2005; Deng, 2009; Luo et al., 2010; Rui \& Yip, 2008). An important feature of Chinese firms is state ownership (Chen \& Young, 2010; Morck et al., 2008). While the role of state ownership in the domestic operation and governance of Chinese firms has been extensively researched (Ding, Zhang, \& Zhang, 2007; Young, Peng, Ahlstrom, Bruton, \& Jiang, 2008; Zou \& Adams, 2008), limited attention has been paid to the role of state ownership in the internationalization of Chinese firms (Chen \& Young, 2010). Our study addresses this research gap by revealing the role of state ownership in Chinese firms' FDI ownership decisions. It provides new insights into internationalization strategies of Chinese firms, which deviate from the predictions of existing theories.

\section{THEORETICAL FRAMEWORK}

Institutional theory argues that social behavior and associated resources are anchored in rule systems and cultural schema (Scott, 2005). Institutions are defined as the "rules of the game” which include both formal (regulatory) and informal (normative and socio-cognitive) categories (North, 1990, Scott, 1995). In a given organizational field, the existing formal and informal rules determine the socially acceptable patterns of organizational structures and actions (DiMaggio \& Powell, 1983). In order to gain legitimacy in its organizational field, a firm will have to adopt the business models, practices and structures established as a standard in the organizational field. Therefore, the isomorphic pressures of institutions can influence and constrain the strategic choices of firms (Davis, Desai, \& Francis, 2000; DiMaggio \& Powell, 1983; Lu, 2002).

Institutional theory has been applied in international business research to provide insights into the strategy-environment interaction in the international operations of firms (Meyer et al., 2009; Peng et al., 2008; Wright, Filatotchev, Hoskisson, \& Peng, 2005). When conducting FDI, firms engage in institutional processes in both home and host countries (Rosenzweig \& Singh, 1991, Xu \& Shenkar, 2002). Firms are therefore subject to isomorphic pressures from home and host country institutional environments. Three types of external institutional pressures are highlighted in the literature. First, within the home country, firms are subject to the home government's regulatory restrictions on 
outward FDI. Home country capital control for outward FDI is prevalent in emerging economies such as China (Cui \& Jiang, 2010; Morck et al., 2008). Similar regulatory restriction may also re-emerge in advanced economies, as governments attempt to impose exit barriers in certain domestic industries (Peng et al., 2008). Second, when entering a foreign country, firms are subject to host country regulatory restrictions on inward FDI. Governments around the world impose different degrees of restrictions on inward FDI to protect their domestic industries and national interests. While direct bans of inward FDI are increasingly rare (UNCTAD, 2005), restrictions on inward FDI still exists in various forms that discriminate against foreign investing firms (Meyer et al., 2009). Third, operating in a foreign country also exposes firms to normative pressures from host country industries and stakeholders. Such pressures correspond with the extent to which the organizational field in a host country tolerates different norms exercised by foreign investing firms. Cultural distance and ethnocentricity can contribute to high host country normative pressures on foreign firms (Mezias et al., 2002; Yiu \& Makino, 2002). In summary, home regulatory, host regulatory, and host normative institutions are the three main external institutions influencing the FDI strategic decisions of firms.

The institutional literature also highlights the factors internal to a firm that can moderate the institutional processes of the firm (DiMaggio, 1988; Scott, 2005). Beyond external institutional pressures, firms form internal institutions based on the internally accepted organizational routines, structures and standards (Kostova \& Zaheer, 1999; Westney, 1993). For firms who are separate from the external institutions, their internal institutions and self-interests may conflict with the expectations of external institutions, which then lead to varied firm responses (Kostova et al., 2008). However, for firms who are affiliated with external institutions, their responses to external institutional pressures are less likely to be a function of conflicts of interests, but rather a function of the consequences of the political affiliation, namely, their resource-dependence on home institutions and the political image perceived by host country institutions.

Based on the three types of external institutional pressures related to FDI, and the political consequences of state ownership, we propose a conceptual model that examines the effect of state ownership in the FDI ownership decisions of firms (Figure 1). From a political perspective, we argue 
that state ownership increases the resource-dependence of a firm on its home country institutions and negatively affects a firm's image building process in host country institutional environments. As such, state ownership moderates the effects of external institutional pressures on the FDI ownership decisions of firms.

Place Figure 1 about here

\section{HYPOTHESES DEVELOPMENT}

In this study we focus on the moderating effect of state ownership on FDI ownership decisions under institutional pressures. Specifically, we examine whether state ownership will strengthen or weaken the effects of the three types of external institutional pressures on the choice of Chinese firms between a joint and a sole ownership structure in their FDIs. While we focus on the role of state ownership in firms’ institutional processes, state ownership may also influence firms’ FDI strategies from other aspects such as firm resource endowment and risk perception (Chen \& Young, 2010; Rugman \& Li, 2007; Yamakawa, Peng, \& Deeds, 2008). Such influences can be independent from external institutional pressures and cause a direct effect of state ownership on FDI ownership decisions. Given the multi-faceted nature of the state ownership effect, we first discuss its potential direct effect on the FDI ownership decisions of firms. From that basis, we then hypothesize the moderating effect of state ownership that influences firms’ FDI ownership decisions under external institutional pressures.

Research on the outward FDIs from emerging economies has highlighted the important role of home country governments in directing and supporting the internationalization activities of domestic firms (Buckley et al., 2007; Yamakawa et al., 2008). Government supports can grant firms resource advantages in overseas investment to compensate their lack of firm-specific advantages (Luo et al., 2010; Rugman \& Li, 2007). Apart from the received government supports (which is separately controlled for in this study), the perceived government backing also differentiates SOEs from other firms in terms of FDI strategic choices. When making strategic decisions, managers of SOEs may factor in the possibility that further supports, either formally or informally, will be available in unexpected adverse circumstances. Such managerial cognition influences decision makers’ risk 
perception and leads managers to downplay the role of risks in outward FDI (Buckley, Clegg, Cross, Liu, Voss, \& Zheng, 2007). Risk perception has implications on firms’ FDI ownership decisions (Ahmed, Mohamad, Tan, \& Johnson, 2002). With perceived government backing combined with below-market cost of capital, SOEs are able to bear short-term loss while retaining full rights to future gains through sole ownership. Meanwhile, the risk-sharing benefits of joint ownership are accordingly devalued. As a result, a higher level of state ownership can increase the likelihood of sole ownership FDI.

An opposite direct effect of state ownership emerges from the political perspective. Prior studies have highlighted the political motivations in Chinese firms’ FDIs (Globerman \& Shapiro, 2009; Zhang et al., 2011). Being a part of the home country institutions, SOEs may carry noncommercial objectives driven by the political interests of the state. These political objectives can influence firms’ FDI ownership decisions. From the home country aspect, the Chinese government encourages firms to engage in collaborative FDI to channel back natural, financial, and technological resources from foreign countries to the domestic economy (Buckley et al., 2007; Child \& Rodrigues, 2005). A joint ownership structure is considered an efficient and effective way to achieve such objectives. From the host country aspect, the state driven objectives of Chinese SOEs are often perceived as non-beneficial, or even harmful, to the host country (Globerman \& Shapiro, 2009). Consequently the institutional barrier for Chinese SOEs to assume ownership and control in their investment in the host country will be high, which also increases the likelihood of a joint ownership FDI. Given the opposing effects discussed above, we control for the direct effect of state ownership in our analyses.

\section{State Ownership and Home Regulatory Institutions}

Like many other emerging economy governments, the Chinese government exerts regulatory restrictions on outward FDI to safeguard state assets, to prevent capital flight, and to direct outward FDI in line with national interests (Cui \& Jiang, 2010; Deng, 2004; Luo et al., 2010). Such regulatory restrictions are implemented through an administrative system in which the Ministry of Commerce is 
authorized as the primary government organization responsible for the approval and administration of the outward FDIs of firms (Deng, 2004; Luo et al., 2010). The main purposes of this administrative system are to exercise capital control on outward FDI and to direct outward FDI activities of firms to adhere to the government's international investment strategies. For example, the government attempts to direct outward FDI to acquire foreign technology and natural resources. It also imposes restrictions on the use of foreign exchange to prevent potential problems related to capital flight (Cui \& Jiang, 2010). Outward FDI projects not in line with the government’s international investment and foreign exchange policies can be rejected or delayed in the approval procedure, thus creating regulatory pressure which constrains the FDI strategic choices of firms.

The level of home regulatory restriction perceived by an individual firm is likely to vary, as the administrative system is evolving constantly over time and across industries to keep pace with the rapid development of China's outward FDI and industrial policy changes. The impact of a high level of perceived home regulatory restriction on a firm's FDI ownership decisions is two-fold. First, it induces isomorphic pressure on firms to follow the practices that have been historically approved by the government. Specifically, during 1990s when Chinese outward FDI started emerging with significant volume, the administrative approval process had generally required firms to adopt the joint venture mode. As a result, record shows that the majority of the approved FDI projects during that period were in the form of joint ventures (Buckley, Cross, Tan, Xin, \& Voss, 2008; Taylor, 2002; Zhan, 1995). This is because, since the implementation of "Open-Door' policy in early 1980s, the Chinese authorities had become familiar with the economic gains associated with the promotion of inward FDI in the form of joint ventures. Consequently, the government sought equivalent advantages of joint ventures (e.g. knowledge transfer, cost saving, and risk sharing) when Chinese firms invested abroad (Buckley et al., 2008; Wang, 2002). Second, while all outward FDI projects are subject to government approval, projects that involve substantial capital contribution from the Chinese side create greater concerns of capital flight and foreign exchange demands, and therefore are subject to more strenuous screening processes. Accordingly, it is relatively easier for a Chinese firm to obtain government approval if the proposed outward FDI is co-funded, ideally with Chinese equity in kind, 
than if it is fully funded by the Chinese investing firm. Therefore, when a Chinese firm perceives high levels of home regulatory restrictions on outward FDI, it is more likely to opt for a joint ownership structure in FDI in order to attain home regulatory approval.

While home regulatory restrictions constrain the strategic choices in FDI of firms, these restrictions can conflict with a firm's internal desires and self-interests, which lead to varied responses from firms. State ownership plays an important role in the responses of firms to home regulatory pressures, because state ownership determines a Chinese firm's political affiliation and subsequently resource-dependence on the home country government, which intensifies the pressure on the firm to conform to home regulatory restrictions. Chinese firms with high levels of state ownership depend heavily on the home country government for critical resource input and police supports. These firms, especially large-sized SOEs, rely on their relational tie with the government to obtain monopolistic advantages in the home market (Rugman \& Li, 2007), and to receive preferential supports when they internationalize (Child \& Rodrigues, 2005; Yamakawa et al., 2008). A firm’s dependence on institutional constituents (in this case, the home country government) affects its response to institutional pressures. High dependence can increase the perceived salience of institutional pressure on firms to conform (Kostova \& Roth, 2002). An organization is less likely to resist institutional pressure when it is dependent on the institutional constituents that exert that pressure (Pfeffer \& Salancik, 1978). Acquiescence is the most probable response in this situation (Oliver, 1991). For Chinese firms, a high level of state ownership indicates a high level of resource-dependence on the home country government, and therefore increases a firm's tendency to conform to, rather than resist, home regulatory restrictions on outward FDI.

Hypothesis 1: State ownership moderates the effect of home country regulatory restrictions on outward FDI on a firm's FDI ownership decision, in that the greater the share of equity held by state entities in the firm, the stronger the positive effect of perceived home country regulatory restrictions on outward FDI on the likelihood of the firm choosing a joint ownership structure in its FDI. 


\section{State Ownership and Host Regulatory Institutions}

Foreign investing firms are subject to regulatory restrictions of host country governments (Gatignon \& Anderson, 1988; Gomes-Cassere, 1990). Host country regulatory institutions apply formal laws, regulations and rules on foreign investors to influence their FDI activities so as to safeguard national interests and maximize local benefits from inward FDI. Although most of the major economies in the world have abolished direct bans on inward FDI (UNCTAD, 2005), host country regulatory restrictions still exist in other forms that may disadvantage foreign investors over host country local firms. For example, foreign investors can be subject to various degrees of discriminatory and restrictive policies that impose difficulties in them acquiring ownership in FDI, limit their access to local resources, require mandatory exporting, and interfere with other operational matters (Meyer et al., 2009). Such regulatory restrictions from host country institutions can disadvantage foreign investing firms when in competition with local firms.

Foreign investing firms need to establish market rights equal to those of local firms when facing regulatory restrictions from host countries. They can reduce their exposure to host regulatory restrictions by forming joint ownership businesses with local firms. Research suggests that host regulatory institutions impose fewer restrictions on a joint ownership business than on an exclusively foreign owned business (Brouthers, 2002; Yiu \& Makino, 2002). A joint ownership structure can also facilitate foreign firms dealing with the uncertainties involved in a host regulatory institutional environment, which may deteriorate or improve over time (Kogut, 1991; Li \& Rugman, 2007). Prior studies supporting this argument found that regulatory pressure increases the likelihood of a joint ownership structure in FDI (Meyer, 2001; Padmanabhan \& Cho, 1996; Yiu \& Makino, 2002).

While host regulatory restrictions on inward FDI exerts institutional pressure on foreign investing firms to opt for a joint ownership structure, state ownership within a Chinese firm can alter the response of the firm to this pressure. Chinese firms with concentrated state ownership are perceived by host country institutions not only as business entities but also as political actors. As a result, these firms are under strict scrutiny by host country regulatory institutions, especially in relation to their potential influences on the local economy of host countries. Chinese firms owned or 
controlled by the state are suspected of carrying political objectives that do not necessarily benefit the commercial interests of shareholders (Chen \& Young, 2010; Zou \& Adams, 2008). They can also be criticized for being heavily subsidized by the government, both directly and indirectly. As such, they are perceived by host regulatory institutions as a potentially negative economic force that may conflict with the business interests of local firms and distort business competition in the host country (Globerman \& Shapiro, 2009; He \& Lyles, 2008; Zhang et al., 2011). The political image associated with state ownership in Chinese investing firms can stimulate politically sensitive and public concerns in host countries, and provoke negative reactions from politicians and the public in the host countries.

While research suggests that firms facing institutional pressures can engage in political negotiation to establish a positive external image and thus attain legitimacy without having to conform to isomorphic pressures (Kostova et al., 2008), the negative political image of state ownership makes such negotiation processes extremely difficult, and at times impossible, to conduct. Host regulatory institutions are concerned with ideological and other political ramifications of Chinese investment with substantial state ownership, and such concerns can be amplified by public and media opinions (Zhang et al., 2011). As alternative legitimizing channels (i.e., negotiation) becomes less viable for the investing firms, any response other than conformity may lead to serious consequences from host regulatory institutions, such as rejection of entry or punitive taxes. In comparison with non-state-owned firms, who can explore alternative ways of obtaining legitimacy, state-owned firms suffer from negative political image and are therefore more sensitive to host regulatory restrictions on inward FDI when making their FDI strategic choices.

Hypothesis 2: State ownership moderates the effect of host country regulatory restrictions on inward FDI on a firm's FDI ownership decision, in that the greater the share of equity held by state entities in the firm, the stronger the positive effect of perceived host country regulatory restrictions on inward FDI on the likelihood of the firm choosing a joint ownership structure in its FDI. 


\section{State Ownership and Host Normative Institutions}

When conducting FDI, foreign investing firms are influenced by social expectations to act in a way that is deemed appropriate in the host countries. The logic of appropriateness is formed by a social collectivity that sustains a normative system with shared norms, values, beliefs and culture (DiMaggio \& Powell, 1983; Francis, Zheng, \& Mukherji, 2009). To be socially legitimate, foreign investing firms need to understand and conform to the host country's normative system. Failure to do so can result in a liability of foreignness, which has negative consequences such as deteriorated social image, loss of brand value and high costs in establishing business networks (Yiu \& Makino, 2002; Zaheer, 1995). Firms are therefore under host country normative pressure to attain local legitimacy. The level of such normative pressure may vary depending on the degree to which the host country's normative system embraces or resists foreign cultures and practices, as well as the normative system distance between the host and home countries (Francis et al., 2009; Ghemawat, 2001).

Prior research outlines two reasons that a joint ownership structure is preferred in an FDI under host country normative pressure. First, normative pressure indicates potential social risk in FDI as the foreign investing firm may become a victim of social stereotyping and differential standards (Kostova \& Zaheer, 1999). Risk exposure of the foreign investing firm can be reduced by a joint ownership structure where risk is shared among partner firms (Anderson \& Gatignon, 1986; Hennart, 1991). Second, conforming to the isomorphic pressure to attain local legitimacy, foreign investing firms need to gain an understanding of the host country’s normative system and adjust their business practices accordingly. A local business partner can facilitate this learning process by bridging the normative system distance with their knowledge of the host country's practices and cultural norms. Overall, host country normative pressure increases the likelihood of a joint ownership structure in FDI (Yiu \& Makino, 2002).

Foreign firms can be more or less subject to host country normative pressure to attain local legitimacy, depending on the perceived image of the firms by local constituents. A foreign firm can be less subject to host country normative pressure if its distinct organizational practice and culture are valued and appreciated by local constituents (Kostova et al., 2008). State ownership, however, carries 
two specific political images that can have negative consequences on the perceived image of a Chinese firm by host country constituents. First, Chinese SOEs deliver the image of the state power of China, which sometimes overrides the business images of these firms. Research indicates that Chinese SOEs convey ideological and cognitive motivations such as 'national pride' in the course of conducting their outward FDI (Hope, Thomas, \& Vyas, 2011). In some host countries, the fact that many Chinese SOEs’ FDIs are results of inter-governmental negotiations between the Chinese and host country governments further demonstrates the state power image of the investing firms. The image of non-commercial objectives and unfair advantages makes it extremely difficult for the investing firm to create positive perceptions about its practice and culture that can be valued and appreciated by host country constituents (Globerman \& Shapiro, 2009; He \& Lyles, 2008). Therefore, an image of state power compromises the viability of alternative legitimizing mechanisms other than isomorphic conformity.

Second, state ownership is also associated with the image of bureaucratic practice and inefficiency. A high level of state ownership leads to acute agency problems due to the separation of control and cash flow rights of owners (Zou \& Adams, 2008). The cash flow rights of state ownership in Chinese firms rest with the central or local government. The control rights, however, are delegated to various government agencies (Delios, Wu, \& Zhou, 2006). This separation of control and cash flow rights results in a lack of monitoring incentive from state owners. When state ownership is high in a firm, there tends to be no effective monitoring of managerial conduct (Chen \& Young, 2010). Moreover, state ownership can influence the appointment of top management personnel in Chinese firms. For example, in firms with high levels of state ownership, governments usually appoint top management positions to former bureaucrats, who typically do not have professional business and management backgrounds (Firth, Fung, \& Rui, 2007; Zou \& Adams, 2008). Such managerial position arrangements reduce operational efficiency of firms and are detrimental to firm performance (Zou \& Adams, 2008). Although an increasing number of Chinese SOEs are undergoing substantial transformation of their operations and management, the outcome is still not evident enough to change the general image of Chinese SOEs as perceived by host country local constituents (He \& Lyles, 
2008). The bureaucratic image combined with the lack of codified information, including reliable accounting data, make the business operation of Chinese SOEs difficult to understand and appreciate from a foreign perspective (Zhang et al., 2011). Similarly, with the influence of the image of state power, the bureaucratic image associated with state ownership also compromises the viability of alternative legitimizing mechanisms. A Chinese investing firm with substantial state ownership would find it difficult to attain host country legitimacy through creating a positive perception with local constituents alone. As non-conforming alternatives become less viable, the firm is more likely to conform to host country normative pressure and dilute its foreign image by adopting host country norms.

Hypothesis 3: State ownership moderates the effect of host country normative pressure to attain local legitimacy on a firm's FDI ownership decision, in that the greater the share of equity held by state entities in the firm, the stronger the positive effect of perceived host country normative pressure to attain local legitimacy on the likelihood of the firm choosing a joint ownership structure in its FDI.

\section{METHODS}

\section{Data Collection}

In this study we test our hypotheses in the context of Chinese outward FDI. We collected data from a survey conducted in 2006 targeting mainland Chinese firms with outward FDI projects. The population was identified from the 2005 Statistical Bulletin of China's Outward Foreign Direct Investment published by the Ministry of Commerce of China, which indicates that, by the end of 2005, there were approximately 5000 Chinese firms that had conducted outward FDI projects. A list of these outward investing firms was kept confidential by the Chinese government and was not accessible to the researchers. As a result, names of outward investing firms were collected manually from multiple sources published by central and provincial Chinese governments ${ }^{2}$. A total of 588 firms with full contact details were identified from these sources. We then designed and targeted our questionnaire for the top decision makers in Chinese outward investing firms. We required the 
respondent to be a senior executive who was directly in charge of his/her firm's outward investment activities at the time of the last FDI entry. In the questionnaire we asked the respondent to reflect on the latest FDI entry of the firm, and answer all questions based on the time of that entry.

We followed a two-step procedure in our survey to improve the response rate. In the first step we conducted telephone pre-screening to identify one potential respondent from each firm who was the most influential decision maker in the firm's latest FDI entry. We presented research information and institutional endorsement via facsimile, and also sought initial consent to participate from the potential respondents. Based on the information obtained from telephone pre-screening, the second step consisted of sending questionnaires to the potential respondents. Two rounds of reminders were subsequently sent to all potential respondents. We received 140 responses from the total of 588 questionnaires sent. As each response was based on a single (and the latest at the time of survey) FDI entry, no multi-level issue was involved in this study. Two responses were deemed unusable because the firms had entered into host countries that disallowed wholly-owned foreign enterprises. We excluded these two cases because the chosen FDI ownership structure was a coercive requirement rather than the outcome of firm decision-making. From the remaining cases, a further six were excluded as the FDI entries occurred prior to 2002, and we determined that there was a risk of bias because the reference event was too distant in the past. As a result, our survey yielded 132 usable responses, which achieved an effective survey response rate of 22.45 per cent.

We assessed the responsiveness of our sample based on the coverage of the sampling frame, absence of non-response bias, and consistency of our sample with the population on key distributional characteristics. Our sampling frame consisted of 588 Chinese outward investing firms that were publically identifiable. These firms were top ranking investing firms revealed in the central government's statistical bulletin, and those approved by eight eastern provinces that collectively contributed to more than seventy per cent of the total outward FDI flow of China (MOFCOM, 2006). Altogether, these firms represented the major forces of Chinese outward FDI by the time of survey. We conducted survey non-response bias tests using both within sample and out-of-sample methods. Following the extrapolation method of detecting non-response bias (Armstrong \& Overton, 
1977), we compared early response group (the first sixty-six responses) and late response group (the rest responses) on key variables such as FDI ownership percentage, state ownership, size, age, and perceptions of institutional environment. No significant difference was found between early and late response groups. To further detect self-selection bias, using Bureau van Dijk’s ORBIS database, we collected non-responding firms' information on firm size, ownership structure, and industry. We then compared the non-respondents with the respondents on these variables. Mean comparison t-tests did not return any significant results. We also followed Heckman's two-stage procedure and estimated a probit model of selectivity on identifying variables including firm size, state ownership and industry dummies. None of the variables were significant and the probit model was also non-significant. The Inverse Mills’ ratio (lambda) calculated from this procedure was also non-significant when entered in subsequent analysis models. No evidence of self-selection bias was found in our data.

Lastly, we compared the industrial and regional distributions between the sample firms and the base population. Information about the population of Chinese outward investing firms was obtained from the 'Statistical Bulletin of China's Outward Foreign Direct Investment' published by the Ministry of Commerce and National Bureau of Statistics of China (MOFCOM, 2006, 2009). As shown in Table 1 below, our sample distributions were largely consistent with the population.

Place Table 1 about here

\section{Measurements}

FDI ownership decision. Our dependent variable is the outcome of the firm's FDI ownership decision at the time of entry, i.e. the initial ownership structure of the firm's foreign affiliate, where firms choose between a joint ownership structure and a sole ownership structure in their FDI. Following prior studies of FDI ownership decisions and entry mode choices (Hennart \& Larimo, 1998; Lu, 2002; Makino \& Neupert, 2000), we used an equity ownership share of 95 per cent as the cut-off between joint ownership and sole ownership structures; the foreign affiliate has a joint ownership structure if the Chinese investing firm held less than 95 per cent equity ownership in the foreign affiliate. We gave the dependent variable a value of one if the foreign affiliate had a joint 
ownership structure, otherwise a value of zero. Foreign affiliate ownership information at the time of entry was collected from our survey and was cross-checked with secondary data ${ }^{3}$. Following the approach of prior studies (Chan \& Makino, 2007; Hennart, 1991), we also used the percentage of equity ownership as an alternative measure of FDI ownership decisions in our robustness test models.

State ownership. In this study we hypothesize the moderating effects of state ownership while controlling for its direct effect. Following prior studies, we measured state ownership in a Chinese firm as the total percentage of equity ownership by the Chinese government and its agencies (Xu \& Zhang, 2008; Zou \& Adams, 2008). Specifically, following Delios et al.’s (2006) definition of 'government owner' we calculated the total share of equity owned by local governments, government ministries, government bureaus, industry companies ${ }^{4}$, state asset investment bureaus, state asset management bureaus, state-owned research institutes and state-owned banks. These owners are ultimately controlled by local, provincial, or national level governments in China (Delios et al., 2006). Sample firms’ ownership data were collected from Bureau van Dijk’s ORBIS database.

Institutional pressures. Prior studies have used two types of measurements for institutional variables - archival index measures (Meyer et al., 2009; Yiu \& Makino, 2002) and survey-based perceptual measures (Brouthers, 2002; Davis et al., 2000; Kostova \& Roth, 2002; Santangelo \& Meyer, 2011). In this study we developed perceptual measures for three reasons. First, Kostova and Roth (2002) suggest that when studying dynamics between institutions and organizations, the measures for institutional variables should be anchored in the specific organizational practice under investigation, because institutional categories are domain- or issue-specific. The specific issue examined in this study is the firm’s FDI ownership decision. However, most archival indices (e.g. Heritage Foundation's economic freedom index and the World Competitiveness indices) measure the general legal and cultural environments of countries rather than those specific to FDI. Second, archival index measures have limitations in regards to their usability. Not all archival indices are updated on a continuous and frequent basis. Missing data and inconsistency in index definitions can create limitations on the usability of archival index measures (Meyer et al., 2009). In our study, we could not access a reliable archival source of Chinese outward FDI and were unable to obtain an index 
measure on the home country regulatory restrictions on outward FDI. Third, survey-based measures have their own limitations as they are less objective than archival index measures and may lead to a common method variance problem. However, researchers argue that the subjectivity of perceptual measures can also be an advantage, because it is the decision-makers' views of their environment that influence their decision-making process (Santangelo \& Meyer, 2011). Moreover, in our study the perceptual nature of survey-based measures did not pose a significant concern about common method because our dependent variable is factual rather than perceptual. Based on these three reasons, we considered the approach of using perceptual measures more appropriate than using archival index measures in our study.

Three institutional variables are included in this study - home country regulatory restrictions on outward FDI (home regulatory pressure), host country regulatory restrictions on inward FDI (host regulatory pressure), and host country normative pressure to attain local legitimacy (host normative pressure). We developed measures of institutional pressures following a three step procedure similar with the approach of Kostova and Roth (2002). In the first step we generated measurement items of home regulatory, host regulatory, and host normative pressures in relation to FDI ownership decision making. A total number of twenty-five items were adapted from prior studies of FDI ownership decisions, FDI entry mode choice and Chinese outward FDI. In the second step, we gave a random list of these items to five managers in a pilot study and asked them to sort the items into the three categories of institutional pressures. We compared the sorting results from these five individuals and excluded the items that appeared across all three categories, in that they were least consistently sorted. We then repeated the process with another three managers, and this time only retained items that achieved perfect matches among the three sorters. Fourteen items were retained and included in the survey questionnaire. The last step involved a principle component analysis (PCA) on the fourteen items obtained in the previous step. As expected, the PCA, using our survey data, returned a three factor solution. We removed items with low factor loadings (less than 0.4 ) and low item-to-total correlations $(\mathrm{r}<0.25)$. Nine items remained after this step. The final scales are presented in Table 2 below. To assess the measurement validity of the scales, we collected secondary host country data on 
political constraints and cultural distance (between the host country and China). We found high correlations between our measure of host regulatory pressure and Political Constraint Index (Henisz, 2000) on "political constraints" (r=0.74) and "executive political restriction" ( $r=0.68)$. We also found a mild but significant positive correlation between our measure of host normative pressure and the cultural distance of host country from China ( $\mathrm{r}=0.35)$, calculated following Kogut and Singh (1988).

Place Table 2 about here

As shown in Table 2, home regulatory pressure was measured by two items reflecting a firm’s perceived pressure to adopt a joint ownership structure in relation to home country institutional procedures. The two items were related to outward FDI approval and foreign exchange approval procedures respectively $(\alpha=0.73)$. Both items were cleanly loaded on one factor. These two home country institutional procedures are highlighted in recent studies of Chinese outward FDI (Deng, 2004; Liu, Buck, \& Shu, 2005; Luo et al., 2010). Host regulatory pressure was measured by three items describing host country policy pressure on inward FDI, foreign firm operation, and equity-based market entry $(\alpha=0.92)$. These three items were cleanly loaded on one factor. All three items were informed by prior studies of FDI ownership decision and entry mode choice using survey methods (Bell, 1996; Kim \& Hwang, 1992). Host normative pressure was measured by four items, with the first two related to host country social attitudes towards foreigners and foreign business, and the later two related to the investing firm's unfamiliarity with host country professional norms and ways of doing business $(\alpha=0.75$ ). All four items had fairly high (above 0.60 ) loadings on one common factor. These items were adapted from prior studies that discuss cultural distance and normative system differences (Francis et al., 2009; Yiu \& Makino, 2002).

Control variables. We controlled for several variables relating to firm capability, host industry and transaction cost. Firm size indicates a firm’s capability of making resource commitments in outward FDI (Agarwal \& Ramaswami, 1992). We measured firm size using the log of the firm’s global sales (in million Renminbi) in the year prior to FDI entry. The experience of doing business overseas influences a firm's perceived risk and uncertainty in conducting FDI, as well as its willingness to commit resources (Anderson \& Gatignon, 1986; Brouthers, 2002). Experience was 
measured by the log-transformed number of years between the firm's first FDI entry and the focal entry reported in the survey. A Chinese firm's ability to conduct FDI is also influenced by the amount of government support received by the firm. Reflecting the three main types of government supports identified by Luo et al. (2010), this variable was measured by three items $(\alpha=0.82)$ related to the levels of government financial, information, and diplomatic supports received by a firm for its outward FDI. Host industry competition also influences the perceived risk of resource commitment in outward FDI. We measured this variable by using three items $(\alpha=0.83)$ related to the perceived number of competitors, competition intensity, and competition induced entry barriers of host country industries (Bell, 1996; Kim \& Hwang, 1992). Host market potential can motivate a foreign investor to preempt the market and make long-term commitments. This variable was measured on two items $(\alpha=0.70)$ related to the host country market growth rate and future growth potential (Bell 1996; Brouthers, 2002). We also controlled for industry effects that may influence a firm's FDI ownership decision. Prior studies generally use a dummy variable to differentiate manufacturing and nonmanufacturing firms (Brouthers, 2002; Kogut \& Singh, 1988), and so, following this practice, we included two dummy variables to control for the effects of manufacturing industry and natural resource industry. Lastly, Research and development $(R \& D)$ intensity of a firm can increase the specificity of the firm's technological assets and expose it to the risk of partner opportunism. Firms may need to adopt a sole ownership structure in FDI to preclude this risk (Anderson \& Gatignon, 1986). Following Kim and Hwang’s (1992) study, we measured R\&D intensity, in comparison with major competitors, using a single survey item.

\section{ANALYSIS AND RESULTS}

\section{Descriptive Statistics and Correlations}

The sample of analysis included FDI entries reported by 132 Chinese outward investing firms. Each firm reported its latest FDI entry up until 2006, which resulted in a sample of 132 independent FDI entries. Among these 132 firms, 53 had no state ownership, 36 were partially state-owned, and 43 were fully state-owned. The average share of state ownership in the sample firms was 45.38 per cent. 
In terms of industry distribution, 78 firms were manufacturing firms, 15 were in natural resource related industries, and the remaining 39 were from other industries, particularly the service industry. Among the 132 FDI entries included in the sample, 52 used a joint ownership structure and 80 used a sole ownership structure. Within the 52 joint ownership cases, the Chinese investing firm had a minority ownership in 11 cases, an equal (50-50) ownership in 10 cases, and a majority ownership in 31 cases. The average share of Chinese ownership in the 132 FDI entries was 82.98 per cent. Some significant correlations were observed between dependent and exploratory variables (see Table 3). The dummy variable joint ownership structure was positively correlated with the three institutional pressure variables, and negatively correlated with firm size, government support, and host industry competition. There were also some significant correlations between exploratory variables, however none of these were of a considerable magnitude. The descriptive statistics and variable correlations are reported in Table 3.

Place Table 3 about here

\section{Hypothesis Test using Logistic Regression}

Our dependent variable was given a value of one if the focal FDI entry was of a joint ownership structure, and a value of zero if it was of a sole ownership structure. Accordingly, we performed binary logistic regression analysis to test our hypotheses. We employed different models to test the direct effect hypotheses and moderating effect hypotheses respectively (see Table 4). In our logistic regression models, a positive regression coefficient means that an increase in the value of the explanatory variable leads to a greater likelihood for the firm to choose a joint ownership structure over a sole ownership structure in its FDI. Following our hypotheses, we expected state ownership to have a significant negative regression coefficient, and its interactions with institutional pressures to have a significant positive regression coefficient.

Place Table 4 about here

A baseline model (Model 1.0) included only the control variables. The model was significant at a level of 0.01 and yielded an Akaike’s Information Criteria (AIC) of 169.23, the highest among 
alternative models. This baseline model correctly predicted 68.94 per cent of the cases, which was a 16.69 per cent improvement from random selection. This was below the expected 25 per cent improvement in classification hit-rate.

Model 1.1 included the direct effect of state ownership and firm perceived institutional pressures. The model was significant at the 0.001 level, and showed significant improvement in model fit over the baseline as evidenced by reduced AIC and a much improved classification hit-rate. The effect of state ownership was non-significant ( $\mathrm{p}=0.138$ ), which could be a result of the opposing effects discussed before. The model returned positive effects of institutional pressures and negative effects of government support. We conducted additional tests to see if these significant results were due to potential endogeneity problems associated with state ownership. Endogeneity problems occur when certain exploratory variables are potentially affected by other variables. In our study, state ownership may affect the focal firm's choice of FDI location. Due to their political liabilities, firms with high levels of state ownership may intentionally avoid host countries with high regulatory and normative pressures. Moreover, firms with high levels of state ownership may receive more government support than other firms. Accordingly, host regulatory pressure, host normative pressure, and government support may be endogenous to state ownership. To test these endogeneity problems, we estimated probit models with endogenous regressors using instrumented variable methods. Three models were estimated where host regulatory pressure, host normative pressure, and government support were respectively instrumented by state ownership. The models returned non-significant estimated rho, indicating that there were no endogeneity issues and thus our original model (model 1.1) should be used.

Models 1.2 through 1.5 tested the hypothesized moderating effects of state ownership. All of these models were significant at the 0.001 level, had smaller AICs than the baseline model, and had more than 25 per cent improvement in model classification hit-rate from random selection. All of the interaction terms, either independently (model 1.2, 1.3, and 1.4) or collectively (model 1.5), had positive coefficients which were statistically significant. The interaction of home regulatory pressure and state ownership was positive and significant in model $1.2(\mathrm{p}=0.032)$ and in model $1.5(\mathrm{p}=0.015)$. 
These results suggest that the greater the share of equity held by state entities in a Chinese firm, the stronger the effect of home country regulatory restrictions on outward FDI on the firm to choose a joint ownership structure over a sole ownership structure in its FDI. Our hypothesis 1 was therefore supported. The interaction of host regulatory pressure and state ownership was positive and significant in model $1.3(\mathrm{p}=0.002)$ and in model $1.5(\mathrm{p}=0.010)$. These results suggest that the greater the share of equity held by state entities in a Chinese firm, the stronger the effect of host country regulatory restrictions on inward FDI on the firm to choose a joint ownership structure over a sole ownership structure in its FDI. Hypothesis 2 was therefore supported. Also, as expected, the interaction of host normative pressure and state ownership was positive and significant in model 1.4 ( $\mathrm{p}=0.001)$ and in model $1.5(\mathrm{p}=0.004)$. These results supported Hypothesis 3 , which states that the greater the share of equity held by state entities in a Chinese firm, the stronger the effect of host country normative pressure on the firm to attain local legitimacy by choosing a joint ownership structure over a sole ownership structure in its FDI.

\section{Robustness Check using Tobit Regression}

To check the robustness of our models, we followed prior studies that measure the outcome of FDI ownership decisions as a continuous variable using the percentage of equity ownership (Chan \& Makino, 2007; Hennart, 1991). We estimated Tobit regression models (see Table 5) because the dependent variable is censored (minimum 10 per cent, maximum 100 per cent). For consistency with previous models and ease of interpretation of results, we reversed the percentage of equity ownership held by the Chinese investing firm as the dependent variable.

Place Table 5 about here

Model 2.1 tested the main effect of state ownership and institutional pressures on FDI ownership. Consistent with our logistic regression results (model 1.1), state ownership remained nonsignificant while the three institutional variables all had positive effects as expected. We also found support for our moderating hypotheses across models 2.2 to 2.5. All models fitted well (chi-square test $\mathrm{p}=0.000$ ) and had reduced AIC compared with the main effect model (Model 2.1) when 
interaction terms were added. In model 2.2, the interaction of home regulatory pressure and state ownership was positive, as was expected, but was, however, non-significant ( $\mathrm{p}=0.138$ ). This result suggests that although high level of home country regulatory restrictions on outward FDI influences a firm to reduce equity ownership in its FDI, this influence does not vary significantly by state ownership in the firm. Therefore Hypothesis 1 was unsupported when FDI ownership structure was measured by the quantity of equity ownership rather than the type of ownership structure. In model 2.3 and 2.4, the interaction terms were positive and significant; suggesting that a greater share of equity held by state entities in a firm strengthens the effects of host regulatory pressure and host normative pressure on the firm to sacrifice ownership for legitimacy, which supported Hypotheses 2 and 3. In general, except for the moderating effect on home regulatory pressure, our logistic regression and Tobit regression models showed consistent results.

Furthermore, we used SOE dummy instead of state ownership (percentage) as the moderator to test the robustness of our models. Using a categorical rather than a continuous measure is in line with prior studies, which suggest that ownership type moderates environment-strategy configuration in the context of an emerging economy (Peng, Tan, \& Tong, 2004; Tan \& Li, 1996). To obtain the value of this dummy variable, we used Bureau van Dijk’s ORBIS database to identify the ultimate owner of a firm. The dummy variable was coded 1 if the ultimate owner of the firm was the Chinese government or its agencies, and a value of 0 if otherwise. We used SOE dummy in both logistic regression and Tobit regression models and found consistent results on the direct effects of institutional pressures and moderating effects of SOE dummy. However, we observed a decrease in significance level of some institutional pressure variables and interaction terms, which suggests that our models are more valid in testing the effects of the share of equity held by state entities in a firm than the dichotomous SOE status of the firm.

\section{DISCUSSION}

This study aims to advance institutional theory and its application in international business research. It addresses the broad research question of 'what factors cause the heterogeneous firm responses to 
external institutional pressures?'. Existing research presents a gap in this theoretical enquiry, as the focus has been exclusively on firms who are structurally separate from external institutions (e.g. multinational firms from advanced economies, see Kostova et al., 2008). Firms who are part of the external institutions (e.g. state-owned firms, especially those from emerging economies) respond to external institutional pressures in a different manner, which has not been systematically examined in the literature. From a political perspective, we extend the current research on firm responses to institutional pressures by investigating the role of state ownership in the institutional processes of firms who are part of the external institutions. State ownership can influence the institutional processes of a firm in the home country by determining the political relationship with, and resourcedependence on, the home country institutions, and in the host country by creating a political image that changes the perception of the firm by host country institutions. These political consequences are particularly evident in the recent surge of outward FDI from emerging economies, especially the institutional challenges faced by Chinese SOEs (Globerman \& Shapiro, 2009; He \& Lyles, 2008; Zhang et al., 2011). Using the empirical context of Chinese outward FDI, this study tests the moderating effect of state ownership in firms' FDI ownership decisions as responses to home and host country institutional pressures.

\section{Main Arguments and Findings}

Institutional theory argues that firms are under institutional pressure to adhere to the formal and informal rules in their institutional fields and to become isomorphic (DiMaggio \& Powell, 1983; Scott, 1995). Firms vary in their responses to the institutional pressures for two reasons. First, firm response can be dependent on the firm's resource-dependence on the institution that exerts the pressure (Oliver, 1991). With a high resource-dependence, a firm is more likely to conform to the institutional pressures to avoid negative consequences (Pfeffer \& Salancik, 1978). From a political perspective, we argue that state ownership can strengthen the home country institutional influence on firms’ strategic choices because state-owned firms are politically affiliated with the home country government and are highly dependent on the home country institutions for critical resource inputs. 
Second, firm response can also vary depending on the viability of alternative mechanisms of legitimizing without having to be isomorphic. Firms that are able to create positive perceptions from institutional constituents are more likely to be accepted for being different and therefore are less subject to isomorphic pressures (Kostova et al., 2008). From a political perspective, we argue that state ownership strengthens the effects of host country institutional pressures because state ownership creates negative images of the investing firm which compromises the viability of alternative legitimizing mechanisms and magnifies the negative consequences of non-conforming responses.

Using survey data on Chinese firms’ FDI entries from 2002 to 2006, we empirically tested the effects of state ownership on firms' FDI ownership decisions under institutional pressures. We controlled for the direct effect of state ownership on outward FDI ownership decisions, which was non-significant. The non-significant results could be due to the opposing effect of state ownership from the resource and political perspectives. As state ownership can be both a resource advantage and a political liability, its direct effect on firms’ FDI ownership decisions maybe multi-dimensional. While controlling for the direct effect, we tested the moderating effects of state ownership on the relationships between external institutional pressures and the likelihood of a firm choosing a joint ownership structure in its FDI. Consistent with prior studies, our results suggest that firms under high levels of external institutional pressures (including home country regulatory restrictions on outward FDI, host country regulatory restrictions on inward FDI, and host country normative pressures to attain local legitimacy) are likely to opt for a joint ownership structure to attain institutional legitimacy and mitigate institutional costs (Chan \& Makino, 2007; Lu, 2002; Yiu \& Makino, 2002). The positive effects of institutional pressures on a joint ownership structure were stronger when the share of equity held by state entities in a firm was high. The moderating effects were also significant when state ownership was measured as a dummy variable separating SOEs from non-SOEs, in that the effects of institutional pressures were stronger for SOEs than non-SOEs. Based on these results, we found substantial support for our hypotheses. 


\section{Research Implications}

This research has sought to advance a political perspective to explain the interaction between firms and their institutional environments in international operations. It contributes to the development of institutional theory in organizational research from an earlier focus on the top-down models of institutional effects toward more interactive models of institutional processes (Scott, 2005). When explaining the variations in firms' responses to external institutional pressures, prior studies mainly take an agentic perspective that highlights what a firm can do to pursue self-interests under institutional pressures (DiMaggio, 1988; Oliver, 1991). However, researchers also note that strategic responses from agentic actors may not be viable in certain institutional fields (Goodrick \& Salancik, 1996); in other words, what a firm can do depends on the dynamics of the institutional field where the firm belongs. A firm can be separate from or affiliated with the external institutions in its institutional field, and the separation or affiliation will have consequences on the viability of the strategic responses of the firm. For example, a strong affiliation with home country state may lead host country constituents to view a foreign investing firm as an agent of a foreign state and thus reduce the viability, or increase the difficulty, of alternative legitimizing efforts of the firm. It is therefore the interaction of institutional pressure and institutional affiliation that influences firm decisions.

This study also advances our understanding of the internationalization strategy of Chinese firms. Although the phenomenal growth of Chinese outward FDI has attracted increasing academic attention (Child \& Rodrigues, 2005; Morck et al., 2008), there is a lack of understanding on the role of state ownership in the internationalization of Chinese firms, despite the fact that state ownership can be an important parameter in explaining the deviation of Chinese firms' FDI strategies from existing theoretical predictions. We suggest that the effect of state ownership on Chinese firms' FDI ownership decisions is multi-faceted. From a resource perspective, state ownership can increase a firm's risk tolerance due to perceived government backing. From a political perspective, state ownership can create institutional barriers for a firm to assume ownership and control in its FDI. While the direct effect of state ownership is complicated by opposing effects from resource and 
political perspectives, our findings support that state ownership can make a firm more subject to external institutional pressures and thus strengthen their effects on the firm's strategic choices.

From a managerial standpoint, our study suggests that firms need to take into account their political affiliations when formulating FDI strategies. While the literature has discussed the image management issues of multinational firms in general (Collinson \& Morgan, 2009), the political images associated with state ownership present a challenge at the group level, which accordingly requires group level solutions. For example, negative publicity of an individual SOE can easily lead to a negative stereotype from public media which may compromise the image building efforts of other SOEs. To change the host country perception, SOEs need to engage in a consistent and coordinated image building process which maximizes the benefits of individual firm efforts. The home country government may play the coordinating role in identifying the key efforts at host country, regional and global levels, and prevent free-riding attempts of individual firms.

\section{Limitations and Future Research Directions}

We identify several limitations of this study which lead to future research directions. First, in this study we measured state ownership as a continuous variable. The measure has its limitations as it does not capture certain qualitative differences in firm ownership structures and associated image perceptions. For example, a fully state-owned firm can be viewed by host country constituents as a pure agent of the Chinese state, which is categorically different from a firm with majority state ownership, and thus subject to institutional expectations of another organizational field. In that case the effect of state ownership may not only be on a firm's response to institutional pressures, but also on the strength and nature of the institutional pressures themselves. Moreover, state ownership is a multi-dimensional phenomenon. State ownership can be divided based on the levels of government association (e.g. central state, provincial and local government ownerships). Research also suggests that the type of state ownership holding entity (e.g. state companies vs. state asset management bureaus) can have different governance effects on firms and consequently influence firms’ strategy and performance outcomes (Chen, Firth, \& Xu, 2009). In future research, we propose a more nuanced 
investigation of state ownership that simultaneously takes into account the non-linear and qualitative difference in the state share of equity, the level of government association of state ownership, and the type of state ownership holding entity.

Second, this study has limitations in its measurement of institutional variables. In this study we developed survey-based measures for the three institutional pressure variables. This approach is advantageous in that researchers can develop issue-specific measures of institutional variables without being constrained by archival data availability. The disadvantage is the loss of a certain degree of objectivity and comparability of findings across studies. This approach also prevents researchers from using self-reported dependent variables (e.g. perceived success of focal FDI entry) due to potential common method variance problems. Future research could develop more objective measures based on factual rather than perceptual information.

Third, this study has its limitations in terms of sampling. Although our theoretical arguments are applicable to a wider range of emerging economies, a single home country sample does not fully demonstrate that potential. While a single home country design can capture the variations of home regulatory pressure across industry, time and firm type, it does not allow us to observe the variations across different home country environments. Also, our sampling is based on official sources which do not capture the Chinese firms that are able to circumvent the official approval procedures of the home country (Cai, 1999). While the volume and characteristics of these unregistered FDI entries are largely unknown, it can be expected that these firms possess certain capabilities that enable them to escape from home country institutional procedures, which may also influence how they respond to institutional pressures overseas. To address these sampling limitations, future research could employ a multi-country and multi-source sampling strategy to provide more generalizable findings.

Finally, as for all quantitative empirical research, this study has limitations in its ability to fully reveal the processes behind statistically significant relationships. Specifically, our focus is to reveal the role of state ownership in moderating the effects of external institutional pressures. Our theoretical arguments center on the political affiliation of SOEs and its consequences. Our data do not allow us to fully disclose the bargaining process of SOEs with their home country government, and 
their legitimizing efforts and failures in host countries. The investigation of these underlying processes warrants a qualitative design utilizing richer case evidence. Qualitative research based on rich and thick process descriptions can better appreciate the complexity of the issue from multiple, and possibly complementary, theoretical lenses (Doz, 2011). We propose that future research should employ a case study method to deepen our understanding of the role of state ownership in firms' institutional processes.

\section{ACKNOWLEDGEMENT}

We are grateful for insightful comments and suggestions received from the editor and three anonymous reviewers.

\section{NOTES}

1. A joint ownership structure is the result of either a partial acquisition or a greenfield joint venture. A sole ownership structure is the result of either a full acquisition or a wholly-owned greenfield investment.

2. Official sources consulted:

- 2004 and 2005 issues of 'Annual statistical bulletin of Chinese outward FDI' published by the Ministry of Commerce (both issues included lists of top 30 Chinese outward-investing firms ranked by their foreign assets and sales figures),

- lists of approved outward FDI projects by 2005 released by the municipal governments of Beijing and Shanghai, and the provincial governments of Fujian, Shandong, Jiangsu, and Zhejiang, and,

- 2005 reports of outward FDI inspection released by the provincial governments of Guangdong and Heilongjiang.

All of these sources were publicly accessible in printed material or on government website at the time of the survey.

3. We also collected foreign affiliate ownership information from Bureau van Dijk’s ORBIS database. Data were collected from ORBIS backup DVDs for the year of entry, to ensure the 
data reflect the firms' ownership decision at the time of entry. We did not find major inconsistency between our survey data and ORBIS data that would change the dichotomous coding of our dependent variable.

4. Most so-called ‘industry companies' in China were central or local government ministries before China's economic reform initiated in 1978. They are fully state-owned and typically run by former government officials.

\section{REFERENCE}

Agarwal, S., \& Ramaswami, S. N. 1992. Choice of foreign market entry mode: Impact of ownership, location and internalization factors. Journal of International Business Studies, 23(1): 1-27.

Ahmed, Z. U., Mohamad, O., Tan, B., \& Johnson, J. P. 2002. International risk perceptions and mode of entry: A case study of Malaysian multinational firms. Journal of Business Research, 55(10): 805-813.

Anderson, E., \& Gatignon, H. 1986. Modes of foreign entry: A transaction cost analysis and propositions. Journal of International Business Studies, 17(3): 1-26.

Anderson, E., \& Coughlan, A. T. 1987. International market entry and expansion via independent or integrated channels of distribution. Journal of Marketing, 51(1): 71-82.

Armstrong, J. S., \& Overton, T. S. 1977. Estimating nonresponse bias in mail surveys. Journal of Marketing Research, 14(3): 396-402.

Bell, J. H. J. 1996. Single or joint venturing? A comprehensive approach to foreign entry mode choice. Hampshire, UK: Avebury.

Brouthers, K. D. 2002. Institutional, cultural and transaction cost influences on entry mode choice and performance. Journal of International Business Studies, 33(2): 203-221.

Brouthers, K. D., \& Hennart, J-F. 2007. Boundaries of the firm: Insights from international entry mode research. Journal of Management, 33(3): 395-425.

Buckley, P. J., Clegg, L. J., Cross, A. R., Liu, X., Voss, H., \& Zheng, P. 2007. The determinants of Chinese outward foreign direct investment. Journal of International Business Studies, 38(4): 499518. 
Buckley, P. J., Cross, A. R., Tan, H., Xin, L., \& Voss, H. 2008. Historic and emergent trends in Chinese outward direct investment. Management International Review, 48(6): 715-747.

Cai, K. G. 1999. Outward foreign direct investment: A novel dimension of China's integration into the regional and global economy. The China Quarterly, 160: 856-880.

Chan, C. M., \& Makino, S. 2007. Legitimacy and multi-level institutional environments: implications for foreign subsidiary ownership structure. Journal of International Business Studies, 38(4): 621638.

Chen, G., Firth, M., \& Xu, L. 2009. Does the type of ownership control matter? Evidence from China's listed companies. Journal of Banking \& Finance, 33(1): 171-181.

Chen, Y., \& Young, M. 2010. Cross-border mergers and acquisitions by Chinese listed companies: A principal-principal perspective. Asia Pacific Journal of Management, 27(3): 523-539.

Child, J., \& Rodrigues, S. B. 2005. The internationalization of Chinese firms: A case for theoretical extension? Management and Organization Review, 1(3): 381-410.

Collinson, S. \& G. Morgan. 2009. Images of the multinational firm. Chichester, UK: John Wiley.

Cui, L., \& Jiang, F. 2010. Behind ownership decision of Chinese outward FDI: Resources and institutions. Asia Pacific Journal of Management, 27(4): 751-774.

Davis, P. S., Desai, A. B., \& Francis, J. D. 2000. Mode of international entry: An isomorphism perspective. Journal of International Business Studies, 31(2): 239-258.

Delios, A., Wu, Z. J., \& Zhou, N. 2006. A new perspective on ownership identities in China's listed companies. Management and Organization Review, 2(3): 319-343.

Deng, P. 2004. Outward investment by Chinese MNCs: Motivations and implications. Business Horizons, 47(3): 8-16.

Deng, P. 2009. Why do Chinese firms tend to acquire strategic assets in international expansion? Journal of World Business, 44(1): 74-84.

DiMaggio, P. J. 1988. Interest and agency in institutional theory. In L. G. Zucker (Eds.) Institutional patterns and organizations: Culture and Environment, 3-21. Cambridge, MA: Ballinger. 
DiMaggio, P. J., \& Powell, W. W. 1983. The iron cage revisited: Institutional isomorphism and collective rationality in organizational fields. American Sociological Review, 48(2): 147-160.

Ding, Y., Zhang, H., \& Zhang, J. X. 2007. Private vs state ownership and earnings management: Evidence from Chinese listed companies. Corporate Governance: An International Review, 15(2): 223-238.

Doz, Y. 2011. Qualitative research for international business. Journal of International Business Studies, 42(5): 582-590.

Ekeledo, I., \& Sivakumar, K. 2004. International market entry mode strategies of manufacturing firms and service firms: A resource-based perspective. International Marketing Review, 21(1): 68-101.

Firth, M., Fung, P. M. Y., \& Rui, O. M. 2007. How ownership and corporate governance influence chief executive pay in China's listed firms. Journal of Business Research, 60(7): 776-785.

Francis, J., Zheng, C., \& Mukherji, A. 2009. An institutional perspective on foreign direct investment. Management International Review, 49(5): 565-583.

Gatignon, H. \& Anderson, E. 1988. The multinational corporation's degree of control over foreign subsidiaries: an empirical test of a transaction cost explanation. Journal of Law, Economics, and Organization, 4(2): 305-336.

Ghemawat, P. 2001. Distance still matters: The hard reality of global expansion. Harvard Business Review, 79(8): 137-147.

Globerman, S., \& Shapiro, D. 2009. Economic and strategic considerations surrounding Chinese FDI in the United States. Asia Pacific Journal of Management, 26(1): 163-183.

Gomes-Casseres, B. 1990. Firm ownership preferences and host government restrictions: An integrated approach. Journal of International Business Studies, 21(1): 1-22.

Goodrick, E., \& Salancik G. R. 1996. Organizational discretion in responding to institutional practices: Hospitals and cesarean birth. Administrative Science Quarterly, 41(1): 1-28.

He, W., \& Lyles, M. A. 2008. China's outward foreign direct investment. Business Horizons, 51(6): 485-491. 
Henisz, W. J. 2000. The institutional environment for economic growth. Economics and Politics, 12: $1-31$.

Hennart, J.-F. 1991. The transaction costs theory of joint ventures: An empirical study of Japanese subsidiaries in the United States. Management Science, 37(4): 483-497.

Hennart, J.-F., \& Larimo, J. 1998. The impact of culture on the strategy of multinational enterprises: Does national origin affect ownership decisions? Journal of International Business Studies, 29(3): 515-538.

Hope, O. K., Thomas, W., \& Vyas, D. 2011. The cost of pride: Why do firms from developing countries bid higher? Journal of International Business Studies, 42(1): 128-51.

Kim, W. C., \& Hwang, P. 1992. Global strategy and multinationals' entry mode choice. Journal of International Business Studies, 23(1): 29-53.

Kogut, B. 1991. Joint ventures and the option to expand and acquire. Management Science, 37(1): 1933.

Kogut, B., \& Singh, H. 1988. The effect of national culture on the choice of entry mode. Journal of International Business Studies, 19(3): 411-432.

Kostova, T., \& Roth, K. 2002. Adoption of an organizational practice by subsidiaries of multinational corporations: Institutional and relational effects. Academy of Management Journal, 45(1): 215233.

Kostova, T., Roth, K., \& Dacin, M. T. 2008. Institutional theory in the study of multinational corporations: A critique and new directions. Academy of Management Review, 33(4): 994-1006.

Kostova, T., \& Zaheer, S. 1999. Organizational legitimacy under conditions of complexity: The case of the multinational enterprise. Academy of Management Review, 24(1): 64-81.

Li, J., \& Rugman, A. M. 2007. Real options and the theory of foreign direct investment. International Business Review, 16(6): 687-712.

Liu, X., Buck, T., \& Shu, C. 2005. Chinese economic development, the next stage: Outward FDI? International Business Review, 14(1): 97-115. 
Lu, J. W. 2002. Intra- and inter-organizational imitative behavior: Institutional influences on Japanese firms' entry mode choice. Journal of International Business Studies, 33(1): 19-37.

Luo, Y., \& Rui, H. 2009. An ambidexterity perspective toward multinational enterprises from emerging economies. Academy of Management Perspectives, 23(4): 49-70.

Luo, Y., Xue, Q., \& Han, B. 2010. How emerging market governments promote outward FDI: Experience from China. Journal of World Business, 45(1): 68-79.

Makino, S., \& Neupert, K. E. 2000. National culture, transaction costs, and the choice between joint venture and wholly owned subsidiary. Journal of International Business Studies, 31(4): 705-713.

Meyer, K. E. 2001. Institutions, transaction costs, and entry mode choice in Eastern Europe. Journal of International Business Studies, 32(2): 357-367.

Meyer, K. E., Estrin, S., Bhaumik, S. K., \& Peng, M. W. 2009. Institutions, resources, and entry strategies in emerging economies. Strategic Management Journal, 30(1): 61-80.

Mezias, S. J., Chen, Y.-R., Murphy, P., Biaggio, A., Chuawanlee, W., Hui, H., Okumura, T., \& Starr, S. 2002. National cultural distance as liability of foreignness: the issue of level of analysis. Journal of International Management, 8(4): 407-421.

MOFCOM. 2006. 2006 Statistical Bulletin of China's Outward Foreign Direct Investment. Beijing, China: Ministry of Commerce and National Bureau of Statistics.

MOFCOM. 2009. 2009 Statistical Bulletin of China's Outward Foreign Direct Investment. Beijing, China: Ministry of Commerce and National Bureau of Statistics.

Morck, R., Yeung, B., \& Zhao, M. 2008. Perspectives on China's outward foreign direct investment. Journal of International Business Studies, 39(3): 337-350.

North, D. C. 1990. Institutions, institutional change, and economic performance. Cambridge, MA: Harvard University Press.

Oliver, C. 1991. Strategic responses to institutional processes. Academy of Management Review, 16(1): 145-179.

Padmanabhan, P., \& Cho, K. R. 1996. Ownership strategy for a foreign affiliate: An empirical investigation of Japanese firms. Management International Review, 36(1): 45-65. 
Peng, M. W., Tan, J., \& Tong, T. W. 2004. Ownership types and strategic groups in an emerging economy. Journal of Management Studies, 41(7): 1105-1129.

Peng, M. W., Wang, D. Y., \& Jiang, Y. 2008. An institution-based view of international business strategy: A focus on emerging economies. Journal of International Business Studies, 39(5): 920936.

Pfeffer, J., \& Salancik, G. R. 1978. The External Control of Organizations. New York: Harper and Row.

Rosenzweig, P. M. \& Singh, J. V. 1991. Organizational environments and the multinational enterprise. Academy of Management Review, 16(2): 340-361.

Rugman, A. M., \& Li, J. 2007. Will China's Multinationals Succeed Globally or Regionally? European Management Journal, 25(5): 333-343.

Rui, H., \& Yip, G. S. 2008. Foreign acquisitions by Chinese firms: A strategic intent perspective. Journal of World Business, 43(2): 213-226.

Santangelo, G. D., \& Meyer, K. E. 2011. Extending the internationalization process model: Increases and decreases of MNE commitment in emerging economies. Journal of International Business Studies, 42(7): 894-909.

Scott, W. R. 1995. Institutions and Organizations. London: Sage.

Scott, W. R. 2002. The changing world of Chinese enterprises: An institutional perspective. In A. S. Tsui \& C. M. Lau (Eds.) Management of enterprises in the People's Republic of China: 59-78. Boston: Kluwer Academic Press.

Scott, W. R. 2005. Institutional theory: Contributing to a theoretical research program. In K. G. Smith \& M. A. Hitt (Eds.), Great minds in management: The process of theory development: 460-484. New York: Oxford University Press.

Tan, J., \& Li, M. 1996. Effects of ownership types on environment-strategy configuration in China's emerging transitional economy. Advances in International Comparative Management, 11: 217250. 
Tan, J. \& Tan, D. 2005. Environment-strategy co-evolution and co-alignment: A staged model of Chinese SOEs under transition. Strategic Management Journal, 26: 141-57.

Taylor, R. 2002. Globalization strategies of Chinese companies: Current developments and future prospects. Asian Business \& Management, 1(2): 209-25.

UNCTAD. 2005. Prospects for Foreign Direct Investment and the Strategies of Transnational Corporations, 2005-2008. New York and Geneva: United Nations.

Wang, M. Y. 2002. The motivations behind China’s government-initiated industrial investment overseas. Pacific Affairs, 75(2): 187-206.

Westney, D. E. 1993. Institutionalization theory and the multinational corporation. In S. Ghoshal \& E. Westney (Eds.), Organizational theory and the multinational corporations: 53-75. New York: St. Martin’s Press.

Wright, M., Filatotchev, I., Hoskisson, R. E., \& Peng, M. W. 2005. Strategy research in emerging economies: Challenging the conventional wisdom. Journal of Management Studies, 42(1): 1-33.

Xu, D. \& Shenkar, O. 2002. Institutional distance and the multinational enterprise. Academy of Management Review, 27(4): 608-618.

Xu, E., \& Zhang, H. 2008. The impact of state shares on corporate innovation strategy and performance in China. Asia Pacific Journal of Management, 25(3): 473-487.

Yamakawa, Y., Peng, M. W., \& Deeds, D. L. 2008. What drives new ventures to internationalize from emerging to developed economies? Entrepreneurship Theory and Practice, 32(1): 59-82.

Yiu, D., \& Makino, S. 2002. The choice between joint venture and wholly owned subsidiary: An institutional perspective. Organization Science, 13(6): 667-683.

Young, M. N., Peng, M. W., Ahlstrom, D., Bruton, G. D., \& Jiang, Y. 2008. Corporate governance in emerging economies: A review of the principal-principal perspective. Journal of Management Studies, 45(1): 196-220.

Zaheer, S. 1995. Overcoming the liability of foreignness. Academy of Management Journal, 38(2): 341-363. 
Zhan, J. X. 1995. Transnationalization of outward investment: The case of Chinese firms.

Transnational Corporations, 4(3): 61-93.

Zhang, J., Zhou, C., \& Ebbers, H. 2011. Completion of Chinese overseas acquisitions: Institutional perspectives and evidence. International Business Review, 20(2): 226-238.

Zou, H., \& Adams, M. B. 2008. Corporate ownership, equity risk and returns in the People's Republic of China. Journal of International Business Studies, 39(7): 1149-1168. 
TABLE 1

Sample Firm and FDI Location Distribution in Comparison with Population

\begin{tabular}{|c|c|c|c|c|c|c|c|c|c|c|}
\hline & & \multicolumn{3}{|c|}{ Industrial distribution of investing firms } & \multicolumn{6}{|c|}{ Regional distribution of FDI location } \\
\hline & & Manufacturing & $\begin{array}{l}\text { Natural } \\
\text { resource }\end{array}$ & Other & Asia & Europe & Africa & $\begin{array}{c}\text { North } \\
\text { America }\end{array}$ & $\begin{array}{c}\text { Latin } \\
\text { America }\end{array}$ & Oceania \\
\hline \multirow{3}{*}{ Sample $(\mathrm{N}=13$} & Number & 78 & 15 & 39 & 68 & 20 & 15 & 18 & 6 & 5 \\
\hline & & & & & & & & & & \\
\hline & Percentage & $59.1 \%$ & $11.4 \%$ & $29.5 \%$ & $51.5 \%$ & $15.2 \%$ & $11.4 \%$ & $13.6 \%$ & $4.5 \%$ & $3.8 \%$ \\
\hline Population* & Percentage & $53.4 \%$ & $8.9 \%$ & $37.7 \%$ & $52.7 \%$ & $15.4 \%$ & $12.5 \%$ & $11.2 \%$ & $4.9 \%$ & $3.3 \%$ \\
\hline
\end{tabular}

* Industry information was obtained from the official statistical bulletin of the survey year (MOFCOM, 2006, Table 6 on Page 15). Location information was not released in early issues and was obtained from MOFCOM (2009, Figure 14 on page 31). 
TABLE 2

Institutional Pressure Constructs

\begin{tabular}{|c|c|c|}
\hline Measurement items on 5-point Likert scale & $\begin{array}{l}\text { Factor } \\
\text { loading }\end{array}$ & Source of adapted items \\
\hline \multicolumn{3}{|l|}{ Home regulatory pressure $\quad(\alpha=0.73)$} \\
\hline $\begin{array}{l}\text { 1. The home country government's official approval procedure favors joint ownership over sole } \\
\text { ownership based outward FDI projects }\end{array}$ & 0.86 & $\begin{array}{l}\text { Deng, 2004, 2009; Liu, Buck, \& } \\
\text { Shu, 2005; Luo et al., } 2010\end{array}$ \\
\hline $\begin{array}{l}\text { 2. Firms are more likely to receive foreign exchange approval from home country authorities if } \\
\text { the proposed outward FDI is jointly rather than solely funded }\end{array}$ & 0.89 & \\
\hline \multicolumn{3}{|l|}{ Host regulatory pressure $\quad(\alpha=0.92)$} \\
\hline 1. There are legal restrictions on foreign direct investment in the host country & 0.93 & Anderson \& Coughlan, 1987; \\
\hline 2. Host country government constrains foreign firms' operations by instituting restrictive policies & 0.92 & Bell, 1996; Brouthers, 2002; \\
\hline $\begin{array}{l}\text { 3. Host country laws and regulations discourage foreign firms from making equity-based market } \\
\text { entries (i.e. FDI) }\end{array}$ & 0.91 & Kim \& Hwang, 1992 \\
\hline \multicolumn{3}{|l|}{ Host normative pressure $\quad(\alpha=0.75)$} \\
\hline 1. In the host country, foreigners are treated unequally compared to native citizens & 0.79 & Ekeledo \& Sivakumar, 2004; \\
\hline 2. There is a social preference of local over foreign businesses in the host country & 0.85 & Francis et al., 2009; Yiu \& \\
\hline $\begin{array}{l}\text { 3. The professional standard in the host country industry is different from that in the home } \\
\text { country industry }\end{array}$ & 0.69 & Makino, 2002 \\
\hline 4. The way of doing business in the host country is different from that in the home country & 0.66 & \\
\hline
\end{tabular}


TABLE 3

Descriptive Statistics and Pearson Correlations

\begin{tabular}{|c|c|c|c|c|c|c|c|c|c|}
\hline & Mean & S.D & 1 & 2 & 3 & 4 & 5 & 6 & 7 \\
\hline 1. FDI ownership (\%) & 82.98 & 24.26 & 1.00 & & & & & & \\
\hline 2. Joint ownership structure & 0.39 & 0.49 & $-0.85 * * *$ & 1.00 & & & & & \\
\hline 3. Firm size & 7.66 & 0.97 & $0.20 *$ & $-0.20 *$ & 1.00 & & & & \\
\hline 4. Experience & 0.44 & 0.82 & 0.08 & -0.06 & $0.36 * * *$ & 1.00 & & & \\
\hline 5. Government support & 2.58 & 0.84 & $0.23 * *$ & $-0.30 * * *$ & 0.02 & 0.09 & 1.00 & & \\
\hline 6. Host industry competition & 3.31 & 0.73 & $0.21 *$ & $-0.18 *$ & 0.07 & -0.06 & $0.23 * *$ & 1.00 & \\
\hline 7. Host market potential & 3.55 & 0.62 & $-0.22 *$ & 0.17 & -0.09 & 0.05 & 0.13 & 0.07 & 1.00 \\
\hline 8. Manufacturing industry & 0.59 & 0.49 & -0.07 & 0.04 & 0.03 & 0.04 & -0.08 & -0.04 & -0.09 \\
\hline 9. Natural resource industry & 0.11 & 0.32 & 0.04 & 0.00 & 0.01 & -0.09 & 0.11 & 0.05 & 0.09 \\
\hline 10. $R \& D$ intensity & 3.02 & 0.93 & -0.09 & 0.06 & 0.10 & 0.04 & -0.06 & -0.10 & 0.04 \\
\hline 11. Host regulatory pressure & 2.38 & 0.85 & $-0.27 * *$ & $0.27^{* *}$ & $-0.23 * *$ & -0.16 & 0.06 & $-0.20 *$ & -0.08 \\
\hline 12. Host normative pressure & 2.56 & 0.78 & -0.14 & $0.20 *$ & -0.13 & -0.04 & 0.08 & 0.15 & 0.04 \\
\hline 13. Home regulatory pressure & 3.34 & 1.03 & $-0.41 * * *$ & $0.33^{* * *}$ & -0.05 & 0.15 & -0.17 & -0.12 & 0.10 \\
\hline 14. State ownership (\%) & 45.38 & 45.30 & -0.09 & 0.07 & 0.06 & -0.03 & -0.01 & -0.04 & 0.07 \\
\hline \multirow[t]{10}{*}{ 15. State-owned enterprise } & 0.46 & 0.50 & -0.11 & 0.12 & 0.03 & -0.07 & -0.04 & -0.08 & 0.07 \\
\hline & & 8 & 9 & 10 & 11 & 12 & 13 & 14 & 15 \\
\hline & 8 & 1.00 & & & & & & & \\
\hline & 9 & $-0.43 * * *$ & 1.00 & & & & & & \\
\hline & 10 & 0.04 & -0.03 & 1.00 & & & & & \\
\hline & 11 & -0.01 & 0.03 & -0.10 & 1.00 & & & & \\
\hline & 12 & -0.07 & 0.02 & -0.04 & $0.24^{* *}$ & 1.00 & & & \\
\hline & 13 & 0.08 & -0.07 & -0.00 & 0.13 & 0.02 & 1.00 & & \\
\hline & 14 & 0.00 & -0.02 & 0.08 & -0.16 & $-0.17^{*}$ & -0.02 & 1.00 & \\
\hline & 15 & 0.03 & 0.00 & 0.04 & -0.10 & $-0.17^{*}$ & 0.02 & $0.96 * * *$ & 1.00 \\
\hline
\end{tabular}

${ }^{*} \mathrm{p}<0.05 ; * * \mathrm{p}<0.01 ; * * * \mathrm{p}<0.001$ 
TABLE 4

Logistic Regression of FDI Ownership Structure

\begin{tabular}{|c|c|c|c|c|c|c|}
\hline DV: Joint $=1$, Sole $=0$ & Model 1.0 & Model 1.1 & Model 1.2 & Model 1.3 & Model 1.4 & Model 1.5 \\
\hline Constant & -0.52 & -0.51 & -0.48 & -0.38 & -0.47 & -0.47 \\
\hline \multicolumn{7}{|l|}{ Control variables } \\
\hline Firm size & $-0.48 *$ & -0.32 & -0.34 & $-0.55 \dagger$ & -0.33 & -0.44 \\
\hline Experience & 0.05 & -0.06 & -0.03 & -0.07 & -0.22 & -0.39 \\
\hline Government support & $-0.71 * *$ & $-0.94 * * *$ & $-0.90 * *$ & $-0.89 * *$ & $-0.95 * * *$ & $-0.74 *$ \\
\hline Host industry competition & -0.26 & -0.24 & -0.22 & -0.35 & -0.39 & $-0.64 *$ \\
\hline Host market potential & $0.43^{*}$ & $0.58 *$ & $0.57^{*}$ & $0.46 \dagger$ & $0.61^{*}$ & $0.63 *$ \\
\hline Manufacturing industry & 0.14 & 0.13 & 0.13 & 0.26 & -0.09 & 0.03 \\
\hline Natural resource industry & 0.14 & 0.17 & 0.13 & 0.26 & 0.17 & 0.13 \\
\hline R\&D intensity & 0.11 & 0.21 & 0.24 & 0.38 & 0.33 & 0.39 \\
\hline \multicolumn{7}{|l|}{ Institutional pressures } \\
\hline Home regulatory pressure (Home) & & $0.72 * *$ & $0.78 * *$ & $0.59 *$ & $0.60 *$ & $1.36^{*}$ \\
\hline Host regulatory pressure (Host) & & $0.67 *$ & $0.64^{*}$ & $1.21 * *$ & $0.57 *$ & $1.47^{*}$ \\
\hline Host normative pressure (Norm) & & $0.62 *$ & 0.44 & $0.47 \dagger$ & $1.04 * *$ & $2.00 *$ \\
\hline \multicolumn{7}{|l|}{ Moderator } \\
\hline State ownership & & 0.36 & 0.39 & 0.34 & 0.37 & 0.29 \\
\hline \multicolumn{7}{|l|}{ Interactions } \\
\hline Home $\times$ State ownership & & & $0.63^{*}$ & & & $1.66^{*}$ \\
\hline Host $\times$ State ownership & & & & $1.38 * *$ & & $1.75^{*}$ \\
\hline Norm $\times$ State ownership & & & & & $1.18 * *$ & $2.51^{* *}$ \\
\hline Observation (N) & 132 & 132 & 132 & 132 & 132 & 132 \\
\hline Log likelihood & -75.61 & -61.93 & -59.31 & -53.90 & -54.67 & -42.58 \\
\hline Likelihood ratio chi-square test & $25.78 * *$ & $53.16 * * *$ & $58.39 * * *$ & $69.21^{* * *}$ & $67.67 * * *$ & $91.85 * * *$ \\
\hline AIC & 169.23 & 149.85 & 146.62 & 135.79 & 137.34 & 117.16 \\
\hline Classification hit-rate (\%) & 68.94 & 81.06 & 81.06 & 81.06 & 79.55 & 84.09 \\
\hline
\end{tabular}

$\dagger \mathrm{p}<0.10 ; * \mathrm{p}<0.05 ; * * \mathrm{p}<0.01 ; * * * \mathrm{p}<0.001$ 
TABLE 5

Tobit Regression of FDI Ownership Structure

\begin{tabular}{|c|c|c|c|c|c|c|}
\hline DV: reversed equity ownership (\%) & Model 2.0 & Model 2.1 & Model 2.2 & Model 2.3 & Model 2.4 & Model 2.5 \\
\hline Constant & -5.70 & -4.72 & -4.31 & -2.14 & -3.74 & -1.57 \\
\hline \multicolumn{7}{|l|}{ Control variables } \\
\hline Firm size & $-10.01 *$ & -6.46 & -6.74 & $-9.68 *$ & -6.93 & $-9.90 *$ \\
\hline Experience & -2.01 & -3.23 & -2.40 & -2.12 & -3.84 & -1.91 \\
\hline Government support & $-13.46 *$ & $-12.01 * *$ & $-10.30^{*}$ & $-8.88 *$ & $-10.83^{*}$ & -6.79 \\
\hline Host industry competition & -7.21 & -4.01 & -3.63 & -5.08 & -4.76 & -5.10 \\
\hline Host market potential & $9.26 *$ & $6.82 \dagger$ & $6.28 \dagger$ & 5.21 & $7.03 \dagger$ & 5.06 \\
\hline Manufacturing industry & 3.81 & 2.94 & 3.12 & 4.94 & 0.97 & 3.51 \\
\hline Natural resource industry & 1.26 & 1.56 & 1.52 & 3.50 & 0.73 & 2.63 \\
\hline$R \& D$ intensity & 2.37 & 3.42 & 3.03 & 4.64 & 3.44 & 3.87 \\
\hline \multicolumn{7}{|l|}{ Institutional pressures } \\
\hline Home regulatory pressure (Home) & & $13.93 * *$ & $12.99 * *$ & $9.78^{*}$ & $10.49 *$ & $7.30 \dagger$ \\
\hline Host regulatory pressure (Host) & & $10.72 *$ & $9.51 *$ & $10.94 * *$ & $9.33 *$ & $8.75 *$ \\
\hline Host normative pressure (Norm) & & $7.57 \dagger$ & 5.24 & 5.18 & $7.74 \dagger$ & 3.86 \\
\hline \multicolumn{7}{|l|}{ Moderator } \\
\hline State ownership & & 3.56 & 2.78 & 0.75 & 2.88 & -0.14 \\
\hline \multicolumn{7}{|l|}{ Interactions } \\
\hline Home $\times$ State ownership & & & 6.51 & & & 5.88 \\
\hline Host $\times$ State ownership & & & & $15.72 * * *$ & & $13.36 * *$ \\
\hline Norm $\times$ State ownership & & & & & $10.98^{* *}$ & $7.97 \dagger$ \\
\hline Observation (N) & 132 & 132 & 132 & 132 & 132 & 132 \\
\hline Log likelihood & -333.34 & -319.38 & -318.25 & -312.25 & -316.07 & -309.54 \\
\hline Likelihood ratio chi-square test & $25.78 * *$ & $53.71^{* * *}$ & $55.95^{* * *}$ & $67.97 * * *$ & $60.31 * * *$ & $73.38 * * *$ \\
\hline AIC & 686.68 & 666.75 & 666.51 & 654.49 & 662.14 & 653.08 \\
\hline Pseudo $\mathbf{R}^{2}$ & 0.037 & 0.078 & 0.081 & 0.098 & 0.087 & 0.106 \\
\hline
\end{tabular}

$\dagger \mathrm{p}<0.10 ;{ }^{*} \mathrm{p}<0.05 ;{ }^{* *} \mathrm{p}<0.01 ;{ }^{* * *} \mathrm{p}<0.001$ 


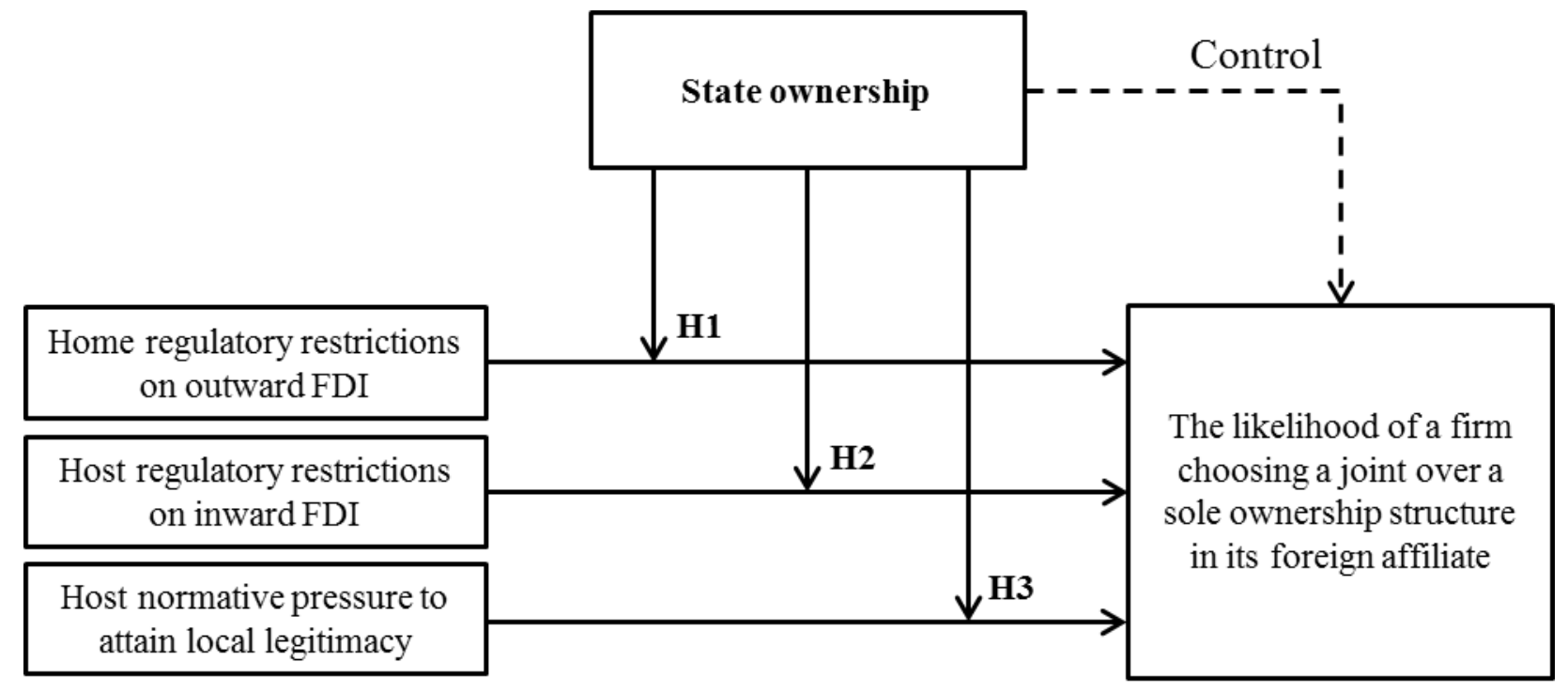

FIGURE 1

State Ownership Effect on FDI Ownership Decisions 